\title{
CONSUMPTION BEHAVIOURS IN THE MARKET OF TOURIST SERVICES. MOTIVATIONS AND NEEDS FOR HOLIDAY TRIPS OF TOURISM AND RECREATION STUDENTS
}

\author{
BLANKA GOSIK \\ University of Lódź branch in Tomaszów Mazowiecki, POLAND \\ e-mail: blanka.gosik@wp.pl
}

\begin{abstract}
KEYWORDS | consumption behaviours in tourism, motivations and needs in tourism
ABSTRACT The aim of this article is to identify students' holiday trips. Particular attention is paid to the issue of needs, motives and tourist behaviours of this social group. Students as a specific community due to limited financial resources, while having a relatively large amount of free time, are an important market segment of tourist trips. Recognition of this specificity is important both for the people involved in the organization of tourism, as well as those providing services necessary for the operation of tourism.
\end{abstract}

\section{Introduction}

Tourism is today one of the most important sectors of mass consumption, being at the same time an important element of lifestyle of wealthy societies. Therefore, it becomes important to study consumer behaviours in the market of tourist services, which in addition to the cognitive aspect, has an important practical significance. This research allows on one hand to determine the size and structure of demand for goods and tourist services allowing to adjust the offer to the 
existing needs. On the other hand, the study makes it possible to deliberately control the behaviours of buyers. Holiday trips are a great way to meet various human needs and are taken due to a number of individual motivations.

\section{The needs and motivations of tourist trips}

The needs are characteristic of human nature. Defining the need, it can be assumed that it is the state of the body caused by lack (or harmful excess) of something that is necessary for the life of the individual, due to its biopsychological structure and/or due to its operating in the society. Such a state violates the psychophysical balance of an individual causing discomfort (tension), which in return motivates a person to take action aimed at removing it (Kieżel, 2010, p. 33). Another very narrow definition identifies the need for a particular product as a tendency to use or possess this product (O'Shaughnessy, 1994, p. 23-24). In order for the need to be satisfied, it must be realized first. The cause of awareness of the need may be: lack of product, obtaining information about new products, disclosure of the new needs, changing of the financial situation, as well as changing expectations for the product (Rudnicki, 2010, p. 16).

The most fundamental way of classifying needs, divides them into general needs (needs) and specific needs (wants) (Foxall, Goldsmith, 1998, p. 186-187), in literature sometimes also referred to as primary and secondary needs. The first, having an abstract nature, do not apply to specific items, but the conditions of human existence. The second, are on the other hand, a desire for certain goods and services aimed at satisfying the primary needs (Kieżel, 2010, p. 34), Primary sources of needs include: physical (biological) requirements of the human body, spiritual properties of the individual and the fact of social life. Despite the fact that consumers have a similar structure of needs, it must be emphasized that in the case of individuals the same needs gain a different hierarchy. They are affected by such factors as time, circumstances or socio-cultural conditions. We can talk about the hierarchy of needs when following their priority (ordering), in accordance with the criteria of urgency to satisfy them (Kieżel, 2010, p. 37). In addition, human needs are constantly changing. This is due to their limitlessness, and the fact that they are soon followed by the development and modification of ways of satisfying them. It is therefore difficult to make an unambiguous classification of needs. An attempt to organize the sphere of needs is presented in Table 1.

Considering the subject of needs from the point of view of consumer behaviour, you should to be aware of the consumption needs. The specificity of consumer needs depends on their economic nature. It is worth mentioning that it is difficult to designate a clear boundary between consumption needs and other needs, because basically every need may be seen at economic and non-economic level (Kieżel, 2010, p. 35). It is worth noting that the needs provoke consumer behaviours in the market, prompting the need for action. On the other hand, motives are the reasons for people's actions and they influence certain consumer behaviour.

A motive is every experience stimulating a person to act or refrain, favouring or refraining from an action. Every human deed is usually determined by a team of individual motives. These factors start a targeted action which is defined as motivation. In other words, motivation is a process 
Table 1. Classification of needs according to selected criteria

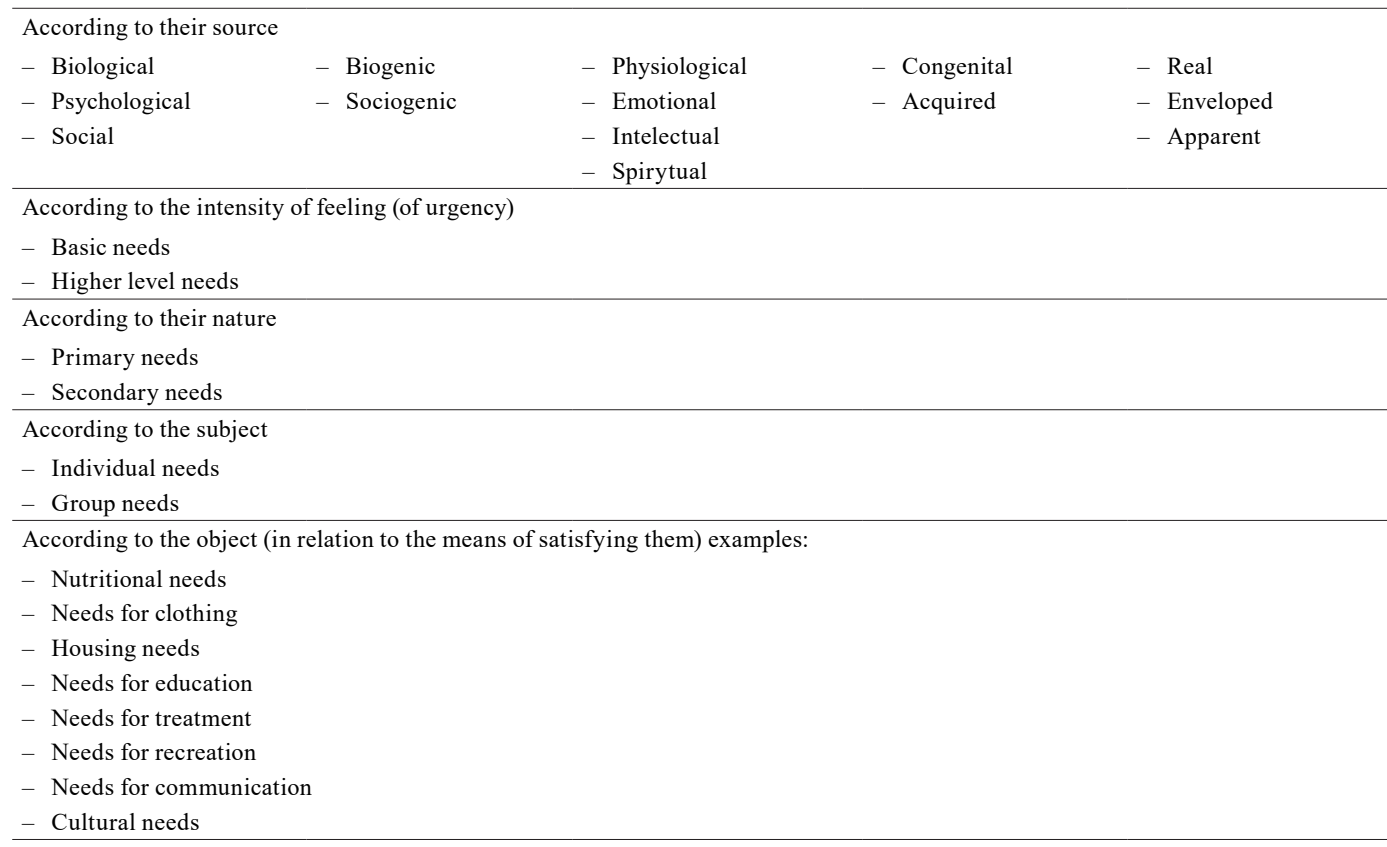

Source: Kieżel (2010), p. 36.

of regulations, controlling human activities, so as to lead to a particular purpose (Reykowski, 1992, p. 157). According to F. Rheinberg, on the other hand, motivation is activating the current focus of the act of living on positively assessed target state (Rheinberg, 2006, p. 18). For a man in order to voluntarily take any action certain conditions must be met: there must be a factor initiating the action, the action must have a value, or it should serve the value, certain external conditions should exist which according to the individual allow for the implementation of specific activities (Zdebski, 1996, p. 84). In the case of motivation of tourist behaviour, there must be something that attracts tourists, as well as something that pushes the tourist to travel. In the literature there are different classifications of motives and motivation in tourism. The summary of the most common factors influencing travel by the tourist are presented in Table 2.

Tahle 2. Factors influencing the decision to travel

\begin{tabular}{ll}
\hline \multicolumn{1}{c}{ Authors } & \multicolumn{1}{c}{ Classification of reasons for travel } \\
\hline 1 & \multicolumn{1}{c}{2} \\
\hline G.M.S. Dann & $\begin{array}{l}\text { The factors leading people to tourist activity (push factors) } \\
\text { Factors influencing the choice of destination (pull factors) }\end{array}$ \\
\hline E.J. Mayo, L. & $\begin{array}{l}\text { Themes of education and culture } \\
\text { Themes of relaxation and enjoyment } \\
\text { Themes of ethnic heritage } \\
\text { Other motives }\end{array}$ \\
\hline
\end{tabular}




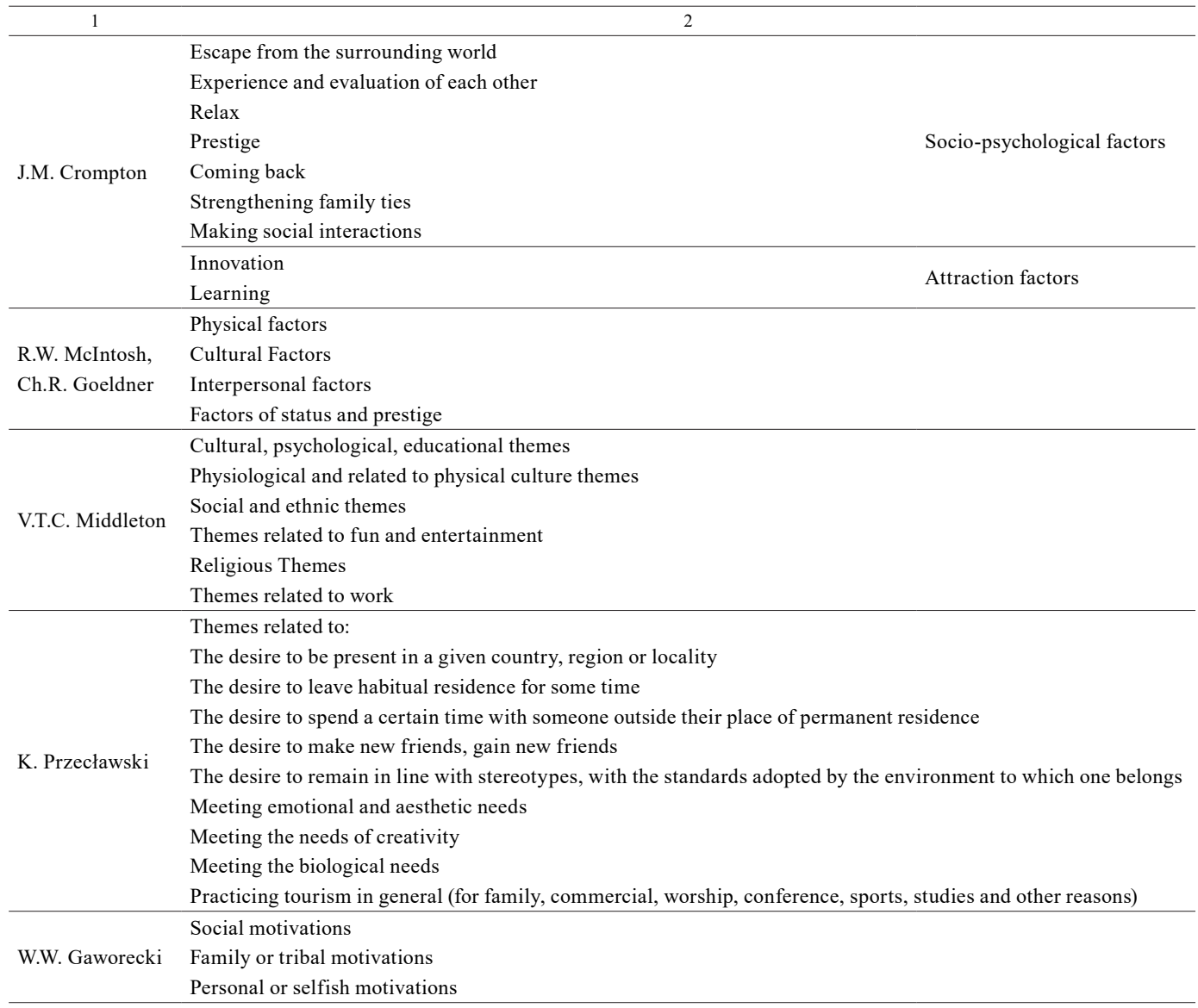

Source: Kozioł (2012), pp. 46-47; Rudnicki (2010), pp. 48-49.

\section{The needs and motivations of student trips}

The research was carried out among students of Tourism and Recreation at the University of Lodz. It took the form of an anonymous survey, which was conducted among 252 students. The questionnaire was developed in such a way to obtain information about the needs and motivations which guided students when deciding on their tourist trips. It was also important to identify consumer and tourist behaviours characteristic of this social group.

The researched student group, was asked to identify the main needs and motivations that guided them in making tourist decisions (Figure 1 and 2). Among the most popular needs of student tourist destination, has been those related to recreation: peace and quiet $(27.5 \%)$, staying away from people (4.9\%) and social and cultural needs: a desire to experience new cultures/people $(15.7 \%)$, the desire of entertainment/events (7.8\%). Subsequently, the surveyed students pointed to 
the physiological needs: recovery of psychophysical strengths $(24.65 \%)$ and spiritual needs: contact with nature $(19.6 \%)$.

The motivations for travel choice of the students surveyed turned out more diverse than the needs. The most common motivation was leisure away from home (20.8\%). Subsequently, young people pointed out admiring beautiful landscapes (11.2\%), experiencing something new (10.8\%) and escape from their surroundings $(9.3 \%)$. Equally frequent proved such motivations as discovering new places (8.9\%), meeting new people (8.5\%) and participation in social activities (8.1\%). A much smaller role in deciding on tourist trips for the students surveyed had such factors as escape from the noise and pollution (5.8), participation in sport (3.5\%), improvement of health (3.1\%) and exploring nature (3.1\%). In turn, the least indications received motivations related to the improvement of physical fitness $(2.3 \%)$, other $(2.3 \%)$, trend $(1.9 \%)$ and coincidence $(0.4 \%)$.

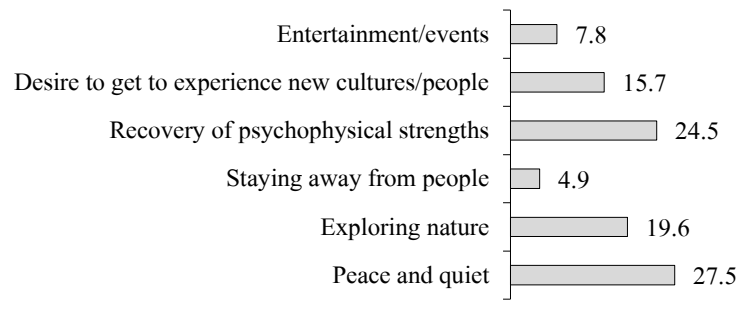

Figure 1. The need for tourist trips (\%) (results do not add up to 100\%)

Source: own study based on research.

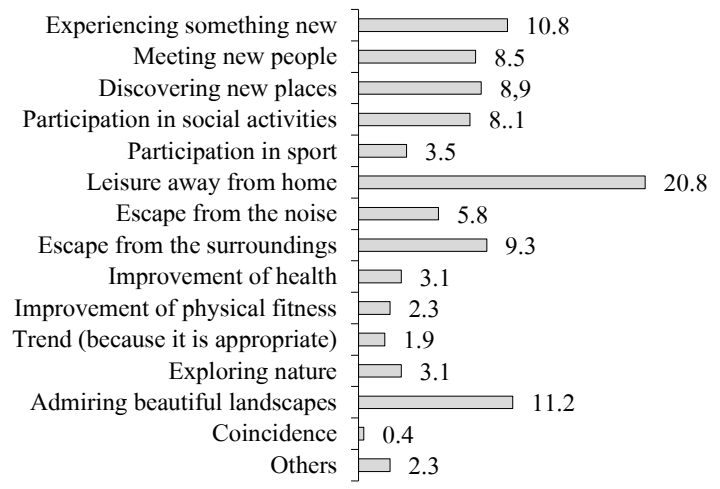

Figure 2. The motivations of tourist trips (\%) (results do not add up to $100 \%$ )

Source: own study based on research. 


\section{Consumer and tourist behaviours}

Identification of consumer behavior in the tourism market is extremely important for the creators of tourist service. Consumer behaviour (or consumption behaviour) represents one element of the wider human behaviour. Consumer behaviours are defined as a coherent whole activities, actions, proceedings relating to the choices in the process of meeting the needs of the consumer in certain social, cultural and economic circumstances (Kieżel, 2003, p. 17-18). Another definition specifies consumption behaviour as the way in which the consumer prioritises needs, chooses the goods and services for their satisfaction and uses possessions (Pohorille, 1980, p. 490). According to another definition, consumer behaviour relates to thoughts, feelings and actions that people take in the process of consumption, as well as environmental factors, that affect those thoughts, feelings and actions (Peter, Olson, 2002, pp. 6-7). On the other hand, F. Hansen treats consumer behavior as all the actions in the perception of consumers that make up for preparation of decision on product selection, making this choice and consuming (Hansen, 1972, p. 15).

In the case of tourist behavior, the distinction is made on the basis of the specific tourist needs. According to T. Żabinska tourist behaviours rely on identifying the needs of tourism in general consumer needs, then acceptance, and consequently the decision: general (division of household budget), modal (the choice of how to fulfill the needs among the many alternatives) and specific (final purchase, or choosing a specific good or service) (Żabińska, 1994, pp. 29-31). Another definition considers tourist behaviours as all activities and actions taken by consumers with certain psychophysical predispositions related to choices in the process of meeting the needs of tourists in certain economic, social, demographic, and geographic conditions. The subject of tourist behavior is the consumer - the tourist, while the object is the process of satisfying the needs of tourists, which takes place during the event and tourist travel and is related to the use of the utility value of tourism products in the space of tourism. It is worth noting that this process is conditioned economically, socially, demographically, culturally, politically, legally, etc. (Niemczyk, 2012, p. 100).

In the case of tourist behaviour among young people, the analysis can be done in a broader context. Tourism for this social group is undoubtedly a good tool for personality development, lifestyle changes upon contact with nature. In addition, it serves regeneration of psychophysical strengths and allows relaxation and recreation (Gierczyk, Ocieczek, 2001, p. 70). According to $\mathrm{K}$. Żelazna, referring to the tourist behaviour of young people one could use a model composed of four stages, the so-called model of consumer behaviour and buyer of tourism services (Żelazna, 2012, pp. 28-31):

1. The first stage - the disclosure of the tourist needs, including physical and spiritual needs.

2. The second stage - the active search for information that is limited to manufacturers and sellers of tourist events, their own experience, the experiences of family or friends and the use of: the Internet, television, radio, advertising and promotional materials.

3. The third stage - consumption, that is, the use of selected tourist offer.

4. The fourth stage - the collection of experiences and consolidation of impressions on the tourist offer. 
The study group of students opts for tourist trips usually once (39.2\%) or twice a year (32.9\%). Almost 30\% of respondents travels frequently, but these are mainly shorter, weekend trips, which in this group of respondents represent $40.8 \%$ of all tourist trips. A weekly or two-week departure is taken respectively by $31.6 \%$ and $18.4 \%$ of respondents. Trips longer than two weeks are $9.2 \%$ of the total number of trips and are mostly trips that combine both leisure and compulsory training which is the condition for completing a degree in the field of Tourism and Recreation. In the case of student mobility, a very large part (40.8\%) is spontaneous trips. These are usually short trips, initiated by a group of friends. The planned trips represent $59.2 \%$ and are mostly longer holiday trips. The length of trips is usually dictated by financial considerations (57\%) and the length of leave (40.5\%). Another factor influencing the length of stay given by the students is apprenticeships (2.5\%). Figure 3 shows the distribution of student tourist trips in a calendar year. The results are not a surprise, for months the most popular are holiday months July (31\%) and August (31.7\%) and June (12.7\%) and September (9.5\%). There are also popular departures associated with May outings (4.8\%). In turn, the winter months are related with New Year's Eve and ski trips.

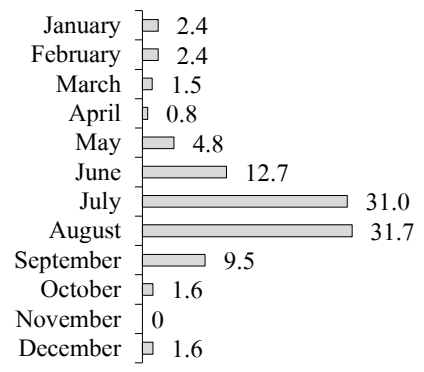

Figure 3. The term of tourist trips (\%) (results do not add up to 100\%)

Source: own study based on research.

For tourist trips students usually choose the company of friends and acquaintances (73.1\%). Trips with the family are less popular (24.7\%) among this social group. Only $2.2 \%$ of young people have decided on a solo trip. A characteristic feature of student mobility is also a way of organizing the trips. The majority of respondents (83.7\%) arranges trips by themselves. Trips bought at a travel agency are taken by $10.1 \%$ of the surveyed students and it must be emphasized that these are rather longer trips, spent with family. Only $6.2 \%$ of the respondents decided on a trip organized by another intermediary. In this group, the most popular destination turned out to be sports camps.

It should be noted that transport plays a very important role in meeting the needs of practicing tourism. First of all, it acts as a mean of communication, which allows tourists both reaching and moving at a tourist destination. In this context, the choice of means of transport for a potential tourist seems very important. There are many criteria for this choice, and the most important are: objectives and types of tourist travel, the quality characteristics of the mean of transport, the cost of travel, distance and geographical location of the destination (Gosik, Zimon, 2014, p. 43). 
Students usually arrive by car at the holiday destination (60\%). Trips by rail and bus were chosen by respectively $15.8 \%$ and $10.5 \%$ of respondents. Flying by plane was picked by $9.5 \%$ of respondents and other forms of transport by $4.2 \%$. Among other forms there were mostly bicycle trips and hitchhiking. In the case of a holiday destination chosen by students the most popular were the sea (25.9\%). Urban tourism appeared to be equally popular among the young. The city as a destination was indicated by $25.3 \%$ of people (Figure 4$)$. Another choices were mountains (16.7\%), rural areas $(12.3 \%)$ and lakes $(13 \%)$. Forests $(6.2 \%)$ proved to be the least popular.

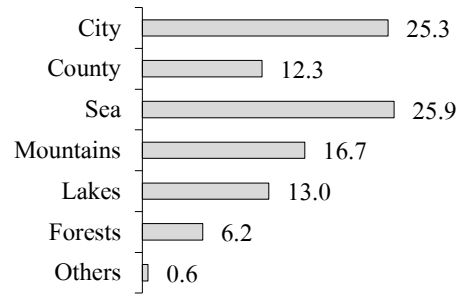

Figure 4. Place of rest during tourist trips (\%) (results do not add up to $100 \%$ )

Source: own study based on research.

When choosing a holiday destinations the researched group of students usually followed the suggestions of family or friends (35.6\%). Further, respondents pointed to coincidence (18.4\%), the need to get to know (13.8\%) and family reasons (12.6\%). Other motives that served surveyed students were social reasons $(8.1 \%)$ and habit $(6.9 \%)$. Only $2.3 \%$ of respondents pointed to health reasons and others, and among others, the most common reason was internships (Figure 5).

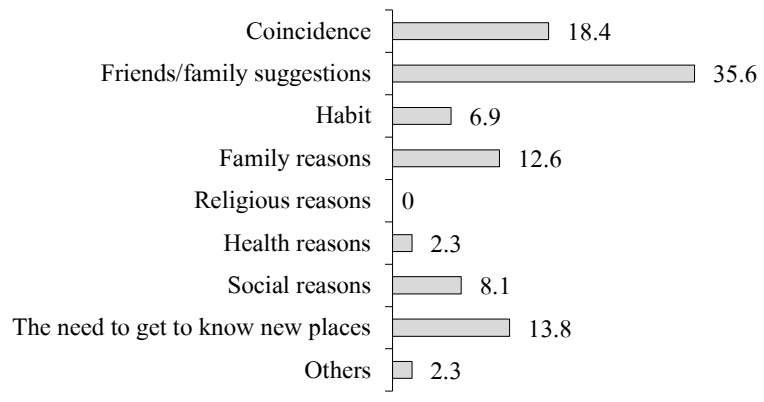

Figure 5. The main reasons for tourist trips (\%) (results do not add up to 100\%)

Source: own study based on research

In the case of the examined group of students the most common place for accommodation turned out to be private accommodation $(24.2 \%)$ and the house of family or friends $(23.2 \%)$. These 
results are not surprising, since this is accommodation, which requires the least financial investment, which in the case of students is a very important issue. Further indications were related to hotel and guesthouse. These bases of accommodation were used most often by respondents who spent holidays with their family. The resort and agritourism was pointed out respectively by $9.1 \%$ and $6.1 \%$ of students (Figure 6). Other responses were camping (4.1\%), camp site (4\%) and the motel $(3.1 \%)$.

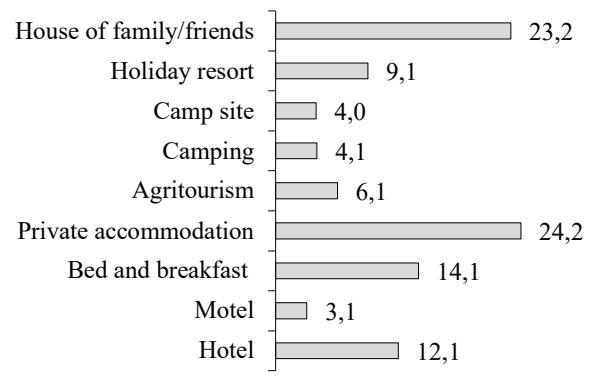

Figure 6. Accommodation used during travel (\%) (results do not add up to 100\%)

Source: own study based on research

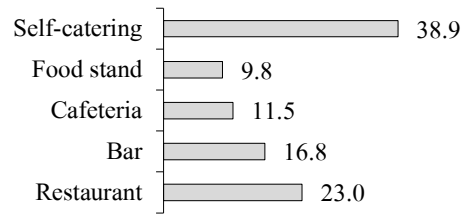

Figure 7. Catering respondents used during travel (\%) (results do not add up to 100\%)

Source: own study based on research.

Indications used for the catering base (Figure 7) are related to the nature of the accommodation. Most of the surveyed students chose a self-catering holiday (38.9\%). Those who stayed in the hotel and bed and breakfast enjoyed the meals in the hotel's restaurants and cafeterias. Bars (16.8\%) and food stands $(9.8 \%)$ were also popular.

\section{Conclusions}

The research have shown that students' holiday trips are characterized by certain specifics resulting from the nature of this social group. Almost $30 \%$ of respondents choose to go away more often, but for a shorter, weekend trips. This is because of economic considerations, as well as the fact that at present a large number of students combines studying and working part-time. On one hand, having their own funds they can afford frequent trips, on the other hand they are dependent 
on the length of leave and the course of study. It turns out that the students usually leave during the summer months. They choose friends and acquaintances to be their travelling company. The most popular destination among young people is the sea, but they are equally eager to cultivate urban tourism. Students usually leave under the suggestions of friends or family. They sleep usually in private houses or in the houses of family / friends, and they choose a self-catering holiday. The main need for mobility of students is the need to rest. On the other hand, considering the motivations that drive them to the decision to leave, the most important is the desire to rest, but also curiosity, the desire to meet new people, as well as the desire to get to know and explore new places and cultures.

\section{Referencens}

Foxall, G., Goldsmith, R. (1998). Psychologia konsumenta dla menedżera marketingu. Warszawa: PWN.

Gierczyk, Z., Ocieczek, B. (2001). Obozy turystyki kwalifikowanej formą aktywności dzieci i młodzieży. Zeszyty Naukowe Wielkopolskiej Wyższej Szkoły Turystyki i Zarządzania w Poznaniu (6).

Gosik, B., Zimon, G. (2014). Usługi transportowe w obsłudze ruchu turystycznego. Zeszyty Naukowe Uniwersytetu Szczecińskiego (843).

Hansen, F. (1972). Consumer Choice Behavior. A Cognitive Theory. New York: The Free Press.

Kieżel, E. (2010). Konsument i jego zachowania na rynku europejskim. Warszawa: PWE.

Niemczyk, A. (2010). Zachowania konsumentów na rynku turystycznym. Kraków: Wydawnictwo Uniwersytetu Ekonomicznego w Krakowie.

O’Shaughnessy, J. (1994). Dlaczego ludzie kupują. Warszawa: PWE.

Peter, J.P., Olson, J.C. (2002). Consumer Behavior and Marketing Strategy. Boston: Irwin-McGraw-Hill.

Pohorille, M. (1980). Mechanizm i kierunki zmian w konsumpcji społeczeństwa polskiego. In: J. Lewandowski, J.J. Wiatr (eds.), Systemy wartości a wzory konsumpcji społeczeństwa polskiego. Warszawa: Wydawnictwo Uniwersytetu Warszawskiego.

Reykowski, J. (1992). Procesy emocjonalne, motywacja, osobowość. Warszawa: PWN.

Rheinberg, F. (2006). Psychologia motywacji. Kraków: WAM.

Rudnicki, L. (2010). Zachowania konsumentów na rynku turystycznym. Kraków: PROKSENIA.

Zdebski, J. (1996). Elementy psychologii turystyki. In: Z. Kruczek (ed.), Pilotaż wycieczek zagranicznych. Kraków: Przedsiębiorstwo Usługowo-Szkoleniowe MENTOR.

Żabińska, T. (1994). Zachowania turystyczne gospodarstw domowych. Uwarunkowania. Prawidłowości. Przyszlość. Katowice: Wydawnictwo Akademii Ekonomicznej w Katowicach.

Żelazna, K. (2012). Uwarunkowania zachowań konsumentów na rynku usług turystycznych. Zeszyty Wyższej Szkoły Turystyki i Rekreacji im. M. Orlowicza (3). 


\section{ZACHOWANIA KONSUMPCYJNE NA RYKU TURYSTYCZNYM. MOTYWACJE I POTRZEBY WYJAZDÓW WAKACYJNYCH STUDENTÓW KIERUNKU TURYSTYKA I REKREACJA}

SŁOWA KLUCZOWE

STRESZCZENIE zachowania konsumpcyjne w turystyce, motywacje i potrzeby w turystyce

Celem artykułu jest identyfikacja wakacyjnych wyjazdów studenckich. Szczególną uwagę zwrócono na zagadnienie potrzeb, motywów i zachowań turystycznych tej grupy społecznej. Studenci jako specyficzna społeczność z racji ograniczonych nakładów finansowych, a jednocześnie z dużą ilością wolnego czasu, stanowią ważny segment rynku wyjazdów turystycznych. Rozpoznanie tej specyfiki ważne jest zarówno dla osób zajmujących się organizowaniem turystyki, jak i świadczących usługi niezbędne dla obsługi ruchu turystycznego. 